\title{
AKTUALISASI KEBIJAKAN CHINA ONE BELT AND ONE ROAD DI INDONESIA MELALUI PEMBANGUNAN KERETA CEPAT JAKARTA-BANDUNG
}

\author{
Handriyanto Wijaya
}

\begin{abstract}
In 2013, China under the leadership of President Xi Jinping announced the One Belt and One Road (OBOR) policy aimed at restructuring the economy in Europe and Asia. In addition OBOR is China's policy to build infrastructure that helps to expedite and advance land and sea-based international trade. Indonesia is one of the countries in Asia that has very good relations with China, which for 70 years has established diplomatic relations with China. Indonesia participated in implementing the China OBOR policy due to the inadequate infrastructure in Indonesia to support trade between countries. The reasons for Indonesia's participation that the Indonesian government has limited state budget to carry out infrastructure development. Therefore, the Indonesian government decided to receive a loan from China for infrastructure development, especially related to the joint train development project from Jakarta to Bandung. Through the implementation of the OBOR policy in the Jakarta-Bandung fast train development project it is hoped that it can improve domestic trade competitiveness even with adequate infrastructure that will support the improvement of Indonesia's competitiveness at the international level
\end{abstract}

Keywords: China, One Belt One Road, High Speed Railways.

\section{PENDAHULUAN}

Seiring dengan globalisasi bahwa dunia terus mengalami perkembangan, begitupun dengan hubungan antar negara. Hubungan antara satu negara dengan negara lainnya dapat dipengaruhi beberapa faktor salah satunya adalah keadaan ekonomi. Perekonomian suatu negara dapat dipengaruhi oleh globalisasi ekonomi dan yang mana suatu kondisi politik internasional yang saling berhubungan satu sama lainnya. Perkembangan ekonomi biasanya sangat dipengaruhi dengan kegiatan 
perdagangan yang baik, sehingga untuk mendukung tersebut salah satunya adalah dengan membangun infrastruktur yang memadai.

Indonesia sebagai negara berkembang yang selama ini telah banyak menjalin hubungan diplomatik dengan negara-negara lain, termasuk salah satunya dengan negara China. Indonesia sudah memiliki hubungan diplomatik dengan China sejak lama, yaitu tanggal 13 April 1950. Hubungan diplomatik tersebut tidak pernah lepas dari keterkaitan dengan kebijakan luar negeri Indonesia yang bebas dan aktif. Kedekatan Indonesia dan China ketika itu sesungguhnya bertumpu pada kedekatan ideologi negara yang tecermin pada sikap para pemimpinnya (Saidiman Ahmad, 2014). Selama menjalin hubungan diplomatik dengan China, Indonesia juga telah menjalin kerjasama-kerjama bilateral di berbagai bidang.

Pada tahun 2013, Presiden China, yaitu Xi Jinping mengeluarkan suatu kebijakan-kebijakan di bidang ekonomi yang cukup ambisius. Salah satu kebijakannya adalah One Belt One Road (OBOR) yang mana akhirnya menjadi perhatian bagi beberapa negara-negara lainnya, termasuk Indonesia. Adapun kebijakan OBOR ini memiliki tujuan untuk menghubungkan ekonomi Eropa dan Asia di bidang infrastruktur, perdagangan serta investasi. Kebijakan China terkait OBOR tersebut memiliki 2 (dua) komponen yang utama, yaitu the Silk Road Economic Belt dan the 21st Century Maritim Silk Road.

Kebijakan Silk Road Economic Belt tersebut memiliki fokus kepada pengembangan jalur darat yang mana bertujuan untuk menghubungkan antara provinsi-provinsi yang tertinggal pada bagian Barat China dengan Eropa melalui Asia Tengah melalui pembangunan di bidang transportasi, yaitu kereta api. Adapun tujuan China menghubungkan antara satu negara dengan negara lainnya tersebut guna mewujudkan sebuah jalan sutera bagi China dengan berbagai kepentingannya.

Kebijakan OBOR ini merupakan salah satu proyek raksasa China yang melintasi 3 (tiga) benua, yaitu Asia, Eropa dan Afrika. Apabila nantinya berhasil, inisiatif OBOR merupakan inisiatif paling ambisius yang 
pernah digagas oleh satu pemerintahan di era kontemporer ini, karena akan mengikutsertakan 65 negara di tiga benua dengan total populasi sekitar 4,4 Miliar orang (Kurniawan, 2016). Adapun salah satu target inisiatif OBOR adalah Indonesia, mengingat Indonesia sebagai negara yang berkembang dan strategis di kawasan Asia Tenggara. Kebijakan persaingan juga membawa perubahan dalam keunggulan komparatif dinamis antara ASEAN (Indonesia) dan Cina (Saputra, 2017).

Mengingat Indonesia masih mengalami ketertinggalan di bidang infrastruktur, termasuk didalamnya transportasi publik maka di masa kepemimpinan Presiden Joko Widodo banyak memfokuskan untuk mengejar ketertinggalan tersebut dengan melaksanakan pembangunan nasional. Fokus utama dari program pembangunan infrastruktur tersebut adalah akses jalan raya, pelabuhan, bandara dan tenaga listrik. Namun untuk mengejar ketertinggalan tersebut, pemerintah Indonesia harus menyiapkan anggaran yang sangat besar. Oleh karena itu, salah satu yang ditempuh Indonesia untuk mencukupinya adalah dengan bantuan pinjaman luar negeri.

Pada akhir September 2015, Pemerintah Indonesia telah mengumumkan bahwa China telah memenangkan tender guna membangun jalur kereta dengan kecepatan tinggi pertama di Indonesia dengan rute Jakarta ke Bandung. Adapun yang menjadi tujuan pembangunan kereta cepat Jakarta - Bandung ini adalah guna mempersingkat waktu tempuh antara Jakarta dengan Bandung yang mana kedua kota tersebut merupakan kota yang paling dinamis dan memiliki mobilitas pergerakan manusia yang terus meningkat dari tahun ke tahun.

Kerjasama Indonesia dengan China dalam rangka pembangunan proyek kereta cepat Jakarta - Bandung ini sejalan dengan kebijakan OBOR dengan segala kepentingannya, namun disisi lain dapat juga sebagai upaya meningkatkan daya saing perdagangan domestik maupun perdagangan internasional Indonesia. Walapun demikian, Indonesia tetap harus 
menyikapi kerjasama dengan China tersebut dengan tetap memperhatikan kepentingan-kepentingan nasional.

\section{KERANGKA PEMIKIRAN}

\section{National Interest}

Sebagai upaya untuk menjelaskan hubungan kerjasama antara Indonesia dengan China dalam melaksanakan visi negaranya masingmasing, bahwa China dengan kebijakan One Belt One Road dengan berlandaskan kepada teori national interest. Teori ini menjelaskan mengenai bagaimana suatu negata dapat memperhatikan dan mendahulukan kepentingan nasionalnya dalam melakukan hubungan dengan negara-negara lainnya. Dengan national interest ini dalam menjalankan visi, kebijakan dan kebutuhan negaranya akan berkaitan dengan tujuan nasionalnya.

Kepentingan nasional atau dalam ungkapan Prancis yaitu raison d'État adalah tujuan dan ambisi negara, baik ekonomi, militer, atau budaya (Bainus \& Rachman, 2018). Menurut Morgenthau menyatakan bahwa kepentingan nasional setiap negara adalah mengejar kekuasaan, yaitu apa saja yang bisa membentuk dan mempertahankan pengendalian suatu negara atas negara lain. Hubungan kekuasaan atau pengendalian ini bisa diciptakan melalui teknik-teknik paksaan maupun kerja sama (Mas'oed, 1994).

Teori kepentingan nasional merupakan turunan dari grand theory, yaitu Realisme. Ide dan asumsi dasar para kaum realis adalah (a) pandanganpesimis atas sifat manusia; (b) keyakinan bahwa hubungan internasional pada dasarnya konfliktual dan bahwa konflik internasional pada akhirnya diselesaikan melalui perang; (c) menjunjung tinggi nilai-nilai keamanan nasional dan kelangsungan hidup negara; (4) skeptisisme dasar bahwa terdapat kemajuan dalam politik internasional seperti yang terjadi dalam kehidupan politik domestik (Jackson \& Sorensen, 2009). Peran 
negara dalam menjamin kesejahteraan masyarakat menjadi tugas pokoknya (Jayn, 2019).

\section{Foreign Policy}

Mark R. Amstutz berpendapat bahwa kebijakan luar negeri sebagai explicit and of governmental officials designed to promote national interests beyond a country's territorial boundries (Jemadu, 2008). Selain itu definisi tersebut terdiri atas tiga tekanan utama yaitu tindakan atau kebijakan pemerintah, pencapaian kepentingan nasional dan jangkauan kebijakan luar negeri yang melawati batas kewilayahan negara (Jemadu, 2008). Oleh karena itu, bahwa semua kebijakan pemerintah yang membawa dampak bagi aktor lain yang berasal dari luar batas wilayahnya maka secara konseptual merupakan bagian dari kepentingan kebijakan luar negeri.

\section{PEMBAHASAN}

\section{Konsep Kebijakan China One Belt and One Road}

Setiap negara dalam sistem keamanan global saling terhubung dan ketergantungan satu sama lain (Daniealdi, 2019). Setiap langkah yang diambil para pembuat keputasan (decision makers) dalam merumuskan kebijakan luar negerinya (foreign policy) harus sesuai dengan kepentingan nasional dan di arahkan untuk mencapai serta melindungi cita-cita kepentingan nasional itu. Adapun yang menjadi kepentingan nasional Tiongkok dapat diklasifikasikan menjadi: a) kepentingan politik; b) Kepentingan keamanan; c) Kepentingan ekonomi; d) Kepentingan budaya (Haikal, 2019).

Istilah belt memiliki makna kepada mengenai serangkaian jalan darat, jalur pipa, kereta api dan infrastruktur lainnya melalui Asia Tengah, sampai ke benua Eropa. Sedangkan istilah Road mengacu kepada serangkaian pelabuhan dan jalur-jalur perdagangan maritim yang masuk melalui Laut China dan Samudera Hindia ke Timur Tengah, pantai timur Afrika dan seterusnya sampai dengan benua Eropa (Shatz, 2016). 
Gambar 1. Rencana Rute One Belt and One Road Initiative

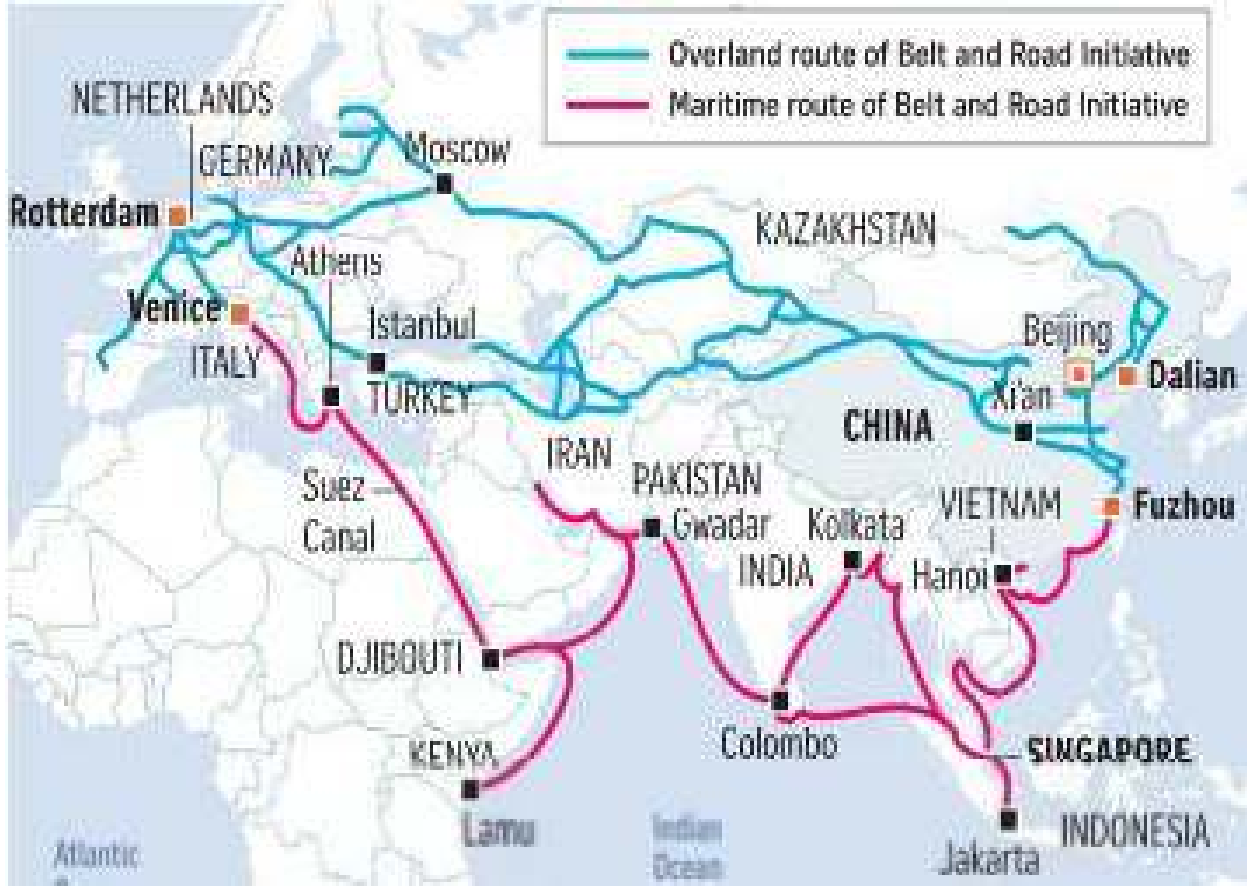

Sumber:https://www.asiagreen.com/en/news-insights/the-belt-and-road-initiativeand-the-rising-importance-of-china-s-western-cities

Inisiatif kebijakan OBOR dibangun oleh China berdasarkan historis, empiris dan praktis. Sesuai sejarah perjalanan negara China bahwa jalur perdagangan yang telah ada sejak berabad-abad lalu. Dengan kebijakan OBOR ini, China ingin mencoba menghidupkan kembali jalur sutera tersebut. Secara empiris bahwa nilai "perdamaian dan kerja sama, keterbukaan dan inklusif, saling belajar dan saling menguntungkan" yang telah tertanam dalam masyarakat China. Secara praktis bahwa suatu kondisi internasional dan domestik suatu negara di sepanjang jalur sutera ini semakin rumit dan pertumbuhan ekonomi dunia yang semakin lemah. Oleh karena itu, China memiliki inisiatif untuk mencoba membangun kembali jalur sutera dengan tujuan agar negara-negara sepanjang jalur dapat bekerja sama dengan saling menguntungkan untuk menghadapi tantangan ekonomi, sosial dan politik internasional (Desheng Hu, 2017). 
Jalur Sutra Ekonomi bertujuan untuk meningkatkan kerjasama ekonomi China dengan negara-negara di kawasan Asia Tengah. Upaya meningkatkan kerjasama ekonomi ini menjadi penting seiring dengan meningkatnya pengaruh politik global China yang dipersepsikan sebagai potensi ancaman bagi negara-negara di Asia Tengah. Indikasi dari persepsi ini dapat kita lihat dari manuver-manuver politik yang dilakukan oleh negara-negara di kawasan ini dalam menjaga hubungannya dengan Rusia dan China (Wong, 2014).

Salah satu kebijakan OBOR terkait dengan fokus China melalui pengembangan jalur darat, disebut sebagai The New Silk Road. Kebijakan Silk Road Economic Belt terdiri dari jaringan rute kereta api, jalan raya, jaringan pipa minyak dan gas, dan proyek infrastruktur lainnya. Melalui jalur ini rencananya akan dibangun koridor The New Eurasia Land Bridge Economic Corridor dan pengembangan koridor ekonomi lainnya: CinaMongolia-Rusia; Cina - Asia Tengah - Asia Barat; semenanjung CinaIndocina; Cina-Pakistan; dan Bangladesh-Cina-India-Myanmar.

Penerapan salah satu kebijakan OBOR, yaitu The New Silk Road ini dapat berpotensi membuat China menjadi pusat perdagangan dunia dengan semua jalur yang diajukan dalam kebijakan tersebut akan menghubungkan China dengan kota-kota penting di dunia terutama Asia dan Eropa. The New Silk Road dapat menjadi salah satu upaya guna membangun kembali gagasan-gasan China sebagai negara tengah dengan semua jalan (serta kereta api, jalur pelayaran, dan lalu lintas udara) yang mengarah ke China.

\section{Kerjasama Antara Indonesia dengan China Dalam Proyek Pembangunan Kereta Cepat Jakarta - Bandung}

Terselenggaranya hubungan bilateral juga tidak terlepas dan tercapainya beberapa kesepahaman antara dua negara yang melakukan hubungan yang mana mereka mengabdi pada kepentingan nasionalnya 
dalam usaha untuk menyelenggarakan politik luar negerinya masingmasing (Leonardo, 2019), begitupun dalam kaitannya kerjasama proyek pembangunan kereta cepat antara Inodnesia dengan China.

Semenjak Bapak Joko Widodo sebagai Presiden Republik Indonesia di tahun 2014 bahwa kebijakan luar negeri terkait perdagangan lebih cenderung memilih membangun hubungan perdagangan internasional dengan China sebagai mitra. Selain itu, berdasarkan hasil survei nasional Lembaga Survei Indonesia pada tanggal 10-15 Juli 2019 terhadap 1.540 responden yang tersebar di 34 provinsi di Indonesia menunjukan China memiliki pengaruh yang lebih besar kepada Indonesia ketimbang Amerika Serikat. (Djayadi Hanan, 2020). Hal tersebut dibuktikan dengan negara yang pertama kali dikunjungi oleh Bapak Presiden Joko Widodo pasca setelah dilantik adalah China, sehingga dapat disimpulkan hubungan diplomatik Indonesia dengan China di era pemerintahan Bapak Presiden Joko Widodo sangat baik.

Adapun yang menjadi agenda kunjungan Presiden Joko Widodo tersebut ke China guna membahas kerjasama ekonomi khususnya di sektor perdagangan, keuangan, infrastruktur dan perindustrian. Selain itu, Indonesia lebih membuka peluang kepada China untuk melakukan investasi langsung diberbagai bidang salah satunya adalah perkembangan infrastruktur di Indonesia. Bahwa dari banyaknya tawaran kerjasama China kepada Indonesia adalah pembangunan infrastruktur dalam bentuk pembangunan transportasi masa, kereta api dengan kecepatan tinggi.

Untuk membangun proyek kereta dengan kecepatan tinggi membutuhkan dana yang sangat besar namun di sisi lain bahwa Indonesia tidak memiliki anggaran yang cukup guna melakukan pembangunan infrastruktur dalam skala nasional, sehingga dalam hal ini pemerintah Indonesia mengalami financial gap antara anggaran negara dengan dana yang harus dikeluarkan untuk pembangunan infrastruktur tersebut. Oleh karena itu, untuk memenuhi pendanaan guna pembangunan proyek kereta 
cepat Jakarta-Bandung ini melibatkan kerjasama dari pihak swasta dengan skema Kerjasama Pemerintah Swasta (KPS) atau Public Private Partnership.

Pemerintah Indonesia memberikan payung hukum atas program KPS tersebut dengan diundangkannya Peraturan Presiden Nomor 67 Tahun 2006 juncto Peraturan Presiden Nomor 13 Tahun 2010 juncto Peraturan Presiden Nomor 56 Tahun 2011 juncto Peraturan Presiden Nomor 66 Tahun 2013 yang mengatur mengenai pola, bentuk dan ketentuan pelaksanaan proyek KPS di Indonesia.

Pekerjaan proyek kereta cepat ini dilakukan dengan prinsip project financing, dimana setiap sektor swasta merupakan pihak yang menjadi sponsor serta memiliki kewajiban guna pembangunan dan/atau mengoperasikan dan merawat setiap sarana infrastruktur. Pendanaan pembangunan kereta cepat Jakarta-Bandung ini diperoleh dari kredit bank dan/atau lembaga pembiayaan lainnya selaku lenders.

Pemerintah selaku pemilik dari proyek infrastruktur memberikan kepada sektor privat/swasta tersebut untuk jangka waktu tertentu berdasarkan kesepakatan perjanjian kerjasama. Kemudian setelah masa perjanjian kerjasama tersebut telah selesai maka infrastruktur tersebut akan diserahkan kembali ke pemerintah.

Mengingat keterbatasan dana yang dimiliki Pemerintah Indonesia guna pembangunan proyek kereta cepat Jakarta-Bandung maka Indonesia perlu melakukan kerjasama dengan negara lain yang memiliki kemampuan pembiayaan yang lebih besar. Hubungan diplomatik Indonesia dan China semakin erat dengan dibuatnya berbagai kerjasama bilateral diantara kedua negara ini, yang mana salah satunya adalah mengenai kerjasama infrastruktur Indonesia dengan China untuk melakukan pembangunan kereta api cepat (high speed railway) dari Jakarta-Bandung yang mana dengan jarak tempuh $142,3 \mathrm{~km}$. Dengan adanya upaya komunikasi lintas pandangan maupun persepsi yang ada, adanya proses bagaimana 
pihak yang terlibat memberikan pengaruh satu sama lain untuk mencapai kepentingannya (Delanova, 2020).

Gambar 2. Rencana Jalur Kereta Cepat Jakarta-Bandung

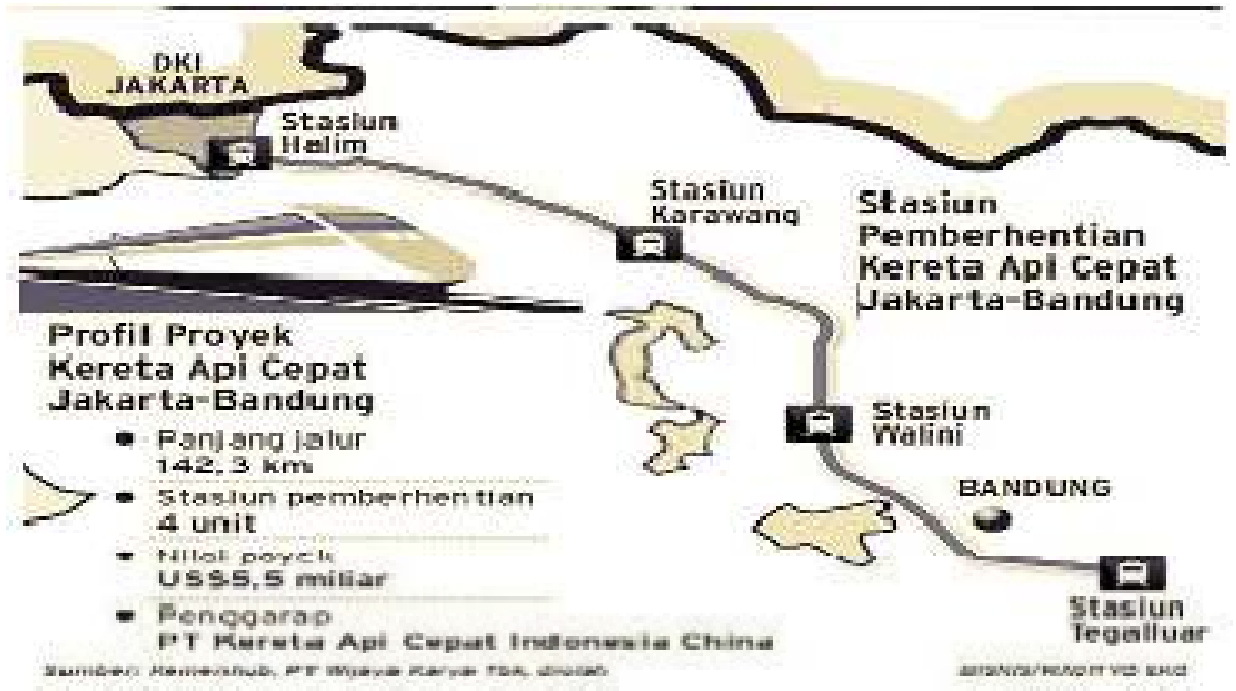

Sumber: https://ekonomi.bisnis.com/read/20190517/9/923947/ngobrol-ekonomimilestone-kereta-cepat-jakarta-bandung

Kerjasama pembangunan proyek kereta cepat Jakarta-Bandung ini dibuat dengan skema Business to Business (B to B) yang mana merupakan hasil dari pembicaraab yang dilakukan secara intens oleh Indonesia dengan beberapa negara yang turut serta dalam tender proyek pembangunan kereta cepat Jakarta-Bandung ini. China sebagai negara terpilih atas tender tersebut adalah China Railway International Co.Ltd, yang mana akan berkerjasama dengan beberapa perusahaan Badan Usaha Milik Negara (BUMN) di Indonesia.

Pembagunan atas kerjasama pembangunan kereta cepat JakartaBandung yang direalisasikan pada masa pemerintahan Bapak Presiden Joko Widodo, menjadi tanda baik hubungan kerjasama bilateral IndonesiaChina. Melalui skema konsorsium bersama PT Kereta Cepat Indonesia Cina (KCIC) yang mana terdiri dari beberapa perusahaan PT Wijaya Karya, PT 
Kereta Api Indonesia, PT Jasa Marga, PT Perkebunan Nusantara, China Railway yang dibangun berdasarkan kesepakatan Indonesia-China ini dapat menjadi parameter bagi kerjasama-kerjasama lainnya. Konsorsium ini didirikan untuk mempermudah pengerjaan proyek kereta cepat dalam masa kepemimpinan Presiden Joko Widodo memiliki visi untuk melakukan modernisasi transportasi massal, memperlancar konektivitas antar kota, dan pembangunan kawasan guna menciptakan sentra ekonomi baruf

Kerjasama pembangunan proyek kereta cepat Jakarta-Bandung merupakan salah satu tujuan China dalam melakukan investasi dan pembangunan infratruktur secara besar-besaran dari 152 negara yang tersebar di Eropa, Asia, Timur Tengah, Amerika Latin dan Afrika. China adalah negara yang paling agresif dalam pembangunan infrastruktur dengan proyek-proyek raksasa, dari jalan raya, kembatan terowongan, hingga kereta cepat.

Terjalinnya kerjasama proyek pembangunan kereta cepat JakartaBandung yang telah disepakati oleh Indonesia dan China membuktikan bahwa sebenarnya kedua negara memiliki kepentingan yang kuat dalam kerjasama dibidang ekonomi dan infrastruktur yang mana salah satunya pembangunan kereta cepat Jakarta-Bandung dapat dikatakan bukan hanya sekedar berinvestasi biasa saja di Indonesia akan tetapi dapat diduga sebagai bentuk dalam merealisasikan kebijakan China, yaitu One Belt One Road.

\section{KESIMPULAN}

Kebijakan One Belt One Road yang digagas oleh Presiden China, yaitu Xi Jinping pada tahun 2013 saat kunjungannya ke negara-negara di kawasan Asia Tengah. Bahwa kebijakan OBOR tersebut terbagi atas dua insiatif, yaitu Kebijakan The New Silk Road ini akan melalui jalur darat (Silk Road Economic Belt) dan melalui laut (The 21st Century Maritime Silk Road). Bahwa tidak dapat dipungkiri terhadap kebijakan OBOR tersebut tentu saja 
terdapat beberapa kepentingan China. Dalam proyek OBOR ini China tidak ragu-ragu untuk mengeluarkan banyak dana guna memberikan bantuanbantuan terhadap negara-negara di wilayah sebagai negara perkembang.

Bantuan-bantuan tersebut tentu saja memiliki tujuan yang berhubungan dengan kepentingan nasional China yang merupakan dasar dari kebijakan luar negeri negaranya. Bahwa kebijakan The New Silk Road memiliki kepentingan ekonomi dan politik, geopolitik. China melakukan berbagai kerjasama dibidang infrastruktur dengan negara-negara berkembang guna menunjang perdagangan dengan negara di Eropa, Asia dan Afrika, yang mana salah satunya adalah negara Indonesia.

Kerjasama Indonesia dengan China guna pembangunan proyek kereta cepat Jakarta-Bandung merupakan salah satu bentuk mengimplementasikan kebijakan OBOR. Pada masa kemimpinan Presiden Joko Widodo berusaha untuk melakukan hubungan diplomatik dengan China agar mau memperbanyak investasinya di Indonesia dengan pemberian beberapa keistimewaan, yang mana salah satunya adalah terpilihnya tender dalam pengerjaan pembangunan kereta cepat JakartaBandung. 


\section{DAFTAR PUSTAKA}

Arif Budisusilo, Ngobrol Ekonomi: Milestone Kereta Cepat Jakarta Bandung, tanggal 17 Mei 2019, diakses melalui https://ekonomi.bisnis.com/read/20190517/9/923947/ngobrolekonomi-milestone-kereta-cepat-jakarta-bandung

Arry Bainus dan Junita Budi Rachman. Kepentingan Nasional dalam Hubungan Internasional, Intermestic: Journal of International Studies Volume 2, No. 2, Mei 2018.

Asia Green Real Estate, the Belt-and-Road initiative and the rising importance of China's Western cities, diakses melalui https://www.asiagreen.com/en/news-insights/the-belt-and-roadinitiative-and-the-rising-importance-of-china-s-western-cities

Delanova, M. O. 2020. Analisis Kebijakan Diplomasi Ekonomi Indonesia Terhadap Pasar Non Tradisional. Jurnal Dinamika Global, 4(02), 382402.

Desheng $\mathrm{Hu}$, Jun Ou, et al. On the Environmental Responsibility of Chinese Enterprises for Their FDIs in Countries within the One Belt and One Road Initiative. The Chinese Journal of Comparative Law (2017), Vol.5 No. 1.

Djayadi Hanan, Survei LSI: Dibanding AS, China Lebih Berpengaruh Bagi RI, tanggal 13 Januari 2020, diakses melalui https://www.cnnindonesia.com/nasional/20200112195647-20464670/survei-lsi-dibanding-as-china-lebih-berpengaruh-bagi-ri

Howard J. Shatz. 2016.U.S. International Economic Strategy in a Turbulent World .Santa Monica: RAND Corporation.

Jayn, W. N. 2019. Fair Trade : Menuju Sebuah Sistem Perdagangan (Baru) Bagi Negara-Negara di Dunia. Jurnal Dinamika Global, 4(01), 210227. 
Jemadu, A. 2008. Politik Global dalam Teori \& Praktik. Yogyakarta: Graha Ilmu.

John Wong."Reviving the Ancient Silk Road: China's New Economic Diplomacy", East Asian Policy, Singapore: East-Asian. 2014.

Leonardo. Diplomasi Budaya Korea Selatan dan Implikasinya Terhadap Hubngan Bilateral Korea Selatan Indonesia. Global Political Studies Journal Vol. 3 No. 1 April 2019.

Mohtar Mas'oed. 1994. Imu Hubungan Internasional Displin dan Metodologi. Jakarta: Pustaka LP3ES Indonesia.

Muhammad Haikal. Kebijakan Cencorship Tiongkok Terhadap Perusahaan Multinasional Dalam Bidang ICT (Information Communication Technologies) (Studi Kasus Google Inc).Global Political Studies Journal Vol. 3 No. 1 April 2019.

Robert Jackson dan Georg Sorensen. 2009. Pengantar Studi Hubungan Internasional. Yogyakarta: Pustaka Belajar,.

Saidiman Ahmad, Poros Jakarta Beijing II, tanggal 15 Desember 2014, diakses melalui https://saifulmujani.com/poros-jakarta-beijing-ii/

Saputra, M. D. H. 2017. Economic Relations of ASEAN (Indonesia) + China After AIIB. Jurnal Dinamika Global, 2 (01), 1 - 22.

Wim Tohari Daniealdi, Memahami Dunia, Merawat Indonesia: Memahami Level Analisis Geo-Politik Dunia. Global Political Studies JournalVolume 3 Nomor 2 Edisi Oktober 2019.

Yandry Kurniawan, One Belt One Road : Agenda Keamanan Liberal Tiongkok?, Jurnal Politica, DPR RI, Vol 7 NO 2 ( 2016). 